\title{
Jakob Müller, jezikoslovec in slovarnik - sedemdesetletnik
}

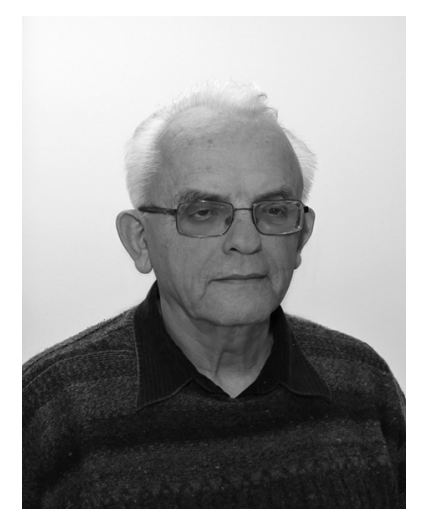

Cobiss: 1.04

Leta 2011 je praznoval sedemdesetletnico naš sodelavec in prijatelj Jakob Müller. Rodil se je 1. marca 1941 na Grosupljem. Leta 1968 je diplomiral iz slavistike na Filozofski fakulteti v Ljubljani. Leta 1970 je postal asistent v leksikološki sekciji Inštituta za slovenski jezik, ki je takrat spadal neposredno k Slovenski akademiji znanosti in umetnosti. Leta 1976 je bil izvoljen v naziv višji strokovni sodelavec, leta 1985 v naziv strokovni svetnik, leta 1994 pa je postal strokovni sodelavec s specializacijo. Od julija 1982 do izdaje zadnje knjige je bil urednik in član glavnega uredniškega odbora Slovarja slovenskega knjižnega jezika (SSKJ). Ob zaključku SSKJ ga je odlikoval takratni predsednik države Milan Kučan, vendar Jakob Müller odlikovanja nekdanjega komunističnega funkcionarja ni sprejel.

Po dokončanju SSKJ je vodil pripravljalna dela za enozvezkovni slovar sodobnega knjižnega jezika in za popravljeno in dopolnjeno izdajo SSKJ. Nobeno delo ni bilo uresničeno, nikoli pa ni bilo pojasnjeno, zakaj.

Ob stoletnici Pleteršnikovega Slovensko-nemškega slovarja (1894-1895) je Jakob Müller v Pišecah pripravil stalno razstavo o Maksu Pleteršniku.

Leta 1995 je na Vrhniki postavil razstavo o delu in življenju Staneta Suhadolnika, ki je bil dolga leta tajnik Inštituta za slovenski jezik in vodja del za SSKJ. Ob razstavi je izdal brošuro z naslovom Jezikoslovec Stane Suhadolnik (1919-1992). V njej je objavil tudi Suhadolnikovo bibliografijo. 
S to razstavo, brošuro in nekaj članki je Jakob Müller želel doseči, da se prizna delo tistih slovenskih jezikoslovcev, ki so bili tako kot nekateri pesniki in pisatelji po drugi svetovni vojni iz političnih razlogov odrinjeni in zamolčani. $\mathrm{Ob}$ Stanetu Suhadolniku je imel takšno usodo Jakob Šolar (Müller je med drugim napisal članek o njem za Enciklopedijo Slovenije), deloma tudi Lino Legiša. Večinoma se ni vedelo, kaj naj bi bilo narobe, obstajal je neki neizraženi dvom.

Ker se v leksikološki sekciji zastavljeni projekti niso nadaljevali, je Jakob Müller leta 2001 postal član sekcije za terminološke slovarje. Tu nadaljuje svoje delo tudi po upokojitvi leta 2002. Ukvarja se zlasti s pravnozgodovinskim slovarjem, ob tem pa je leta 2011 predelal, posodobil in dopolnil ter pripravil za tisk knjigo Slovensko tehniško izrazje: jezikovni priročnik.

Jakob Müller spada med tiste slovenske izobražence, ki delujejo na različnih področjih - na ozko znanstvenem, na področju slovenske kulture in na področju lokalne kulture, zgodovine, etnologije -, na vseh pa temeljito. Tak način delovanja je človeku nekako vrojen, mu je državljansko in človeško poslanstvo, temelji na pripadnosti narodu in ožjemu bivanjskemu območju, česar pa država Slovenija, ki so ji za znanstveno uspešnost pomembne točke, zlasti iz objav v tujih jezikih, ne podpira in ne nagrajuje.

Naš sodelavec uresničuje svoje poslanstvo s slovaropisnim delom, sodelovanjem na domačih in mednarodnih znanstvenih srečanjih, z objavljanjem znanstvenih in strokovnih člankov, organizacijo kulturnih prireditev na Grosupljem in v sosednjih krajih, s pripravo znanstvenih srečanj, urejanjem zbornikov, s sodelovanjem z zamejskimi Slovenci v Italiji in na Madžarskem ter z goranskimi Hrvati, z delovanjem v komisiji za jezik Ministrstva za kulturo Republike Slovenije ipd.

Jakob Müller je eden najbolj eminentnih slovenskih slovarnikov. K slovenskemu slovaropisju je prispeval teoretično in praktično. Njegova slovaropisna pot se je začela leta 1970 z vključitvijo v leksikološko sekcijo Inštituta za slovenski jezik, v skupino, ki je izdelovala SSKJ. Pridružil se je Antonu Bajcu, Francetu Tomšiču, Linu Legišu, Jakobu Riglerju, Stanetu Suhadolniku, Mariji Janežič, Joži Meze, Ivanki Černelič, Mileni Hajnšek-Holz, Zvonki Leder-Mancini, Francetu Novaku, Marti Silvester, Adi Vidovič-Muha in drugim.

S prihodom v leksikološko sekcijo je postal redaktor SSKJ. Takrat je delo potekalo tako, da je redaktor dobil izpise iz literature (rokopisne in napisane na pisalni stroj), ki so jih pripravili izpisovalci in urejevalci gradiva. Redaktor je gradivo pomensko analiziral in napisal redakcijo. Müller je gradivo zelo natančno analiziral. V šali se je govorilo, da iz treh listkov napravi pet pomenov. V delo je tako dobival težja gesla. Naslednja faza dela je bil pregled, ki so ga opravljali izkušenejši redaktorji. Za njegove preglede je bilo znano, da je temeljito pregledal gradivo, ki ga je imel na voljo redaktor, in večino redakcij napisal skorajda na novo.

$\mathrm{Ob}$ redakciji slovarskih člankov za SSKJ pa so nastajala tudi teoretična dela, zlasti s področja pomenoslovja samostalnika: Pomenske skupine in pomenska zgradba samostalnika (1980), Pomenoslovje samostalniških besed (1981/82), Slovarsko pomenoslovje samostalnikov (1982) in Leksikografsko razvrščanje samostalniških pomenov (1993). Ti članki odražajo veliko razgledanost avtorja po domači in tuji pomenoslovni literaturi in nove predloge, temelječe zlasti na odnosih 
med besedami. Temelj pomenske analize posamezne besede je njeno mesto $\mathrm{v}$ hierarhiji nadpomenk in podpomenk. Pri večpomenskih besedah se postavlja vprašanje, kateremu od pomenov dati prednost. Müller postavlja tri načela, po katerih se lahko poišče prvi pomen: (a) osnovni pomen, iz katerega izhajajo nadaljnji pomeni, v naslednjih pa naj bi bilo izkazano pomensko širjenje ali oženje, (b) stvarni pomen (pri kolenu je to del telesa), (c) vzporedna (npr. belec, rjavec) ali zaporedna vezava pomenk (pri jeklu je prvi pomen vrsta snovi, sledi predmet in nato trdota). Pomenoslovni članki so tudi najpogosteje navajani Müllerjevi članki, zlasti v slovenskem besedoslovju in slovaroslovju, kar kaže na njihovo pomembnost in temeljitost.

Odgovor na vprašanje, kako nadaljevati delo pri SSKJ, je Müller iskal tudi v pregledu kritik. V Jeziku in slovstvu (1972/73) je skupaj z Borislavo Košmrlj-Levačič objavil članek Pregled tujih kritičnih mnenj in pripomb o Slovarju slovenskega knjižnega jezika. Ob zaključku SSKJ pa je leta 1996 objavil obsežno razpravo s povzetki in z bibliografijo kritičnih mnenj z naslovom Slovar slovenskega knjižnega jezika in kritika z bibliografijo (1960-1992). Članek naj bi bil tudi osnova za delo pri nadaljnjih splošnih slovarjih, zlasti pri t. i. enozvezkovniku. Za strokovni posvet o novem slovarju slovenskega jezika, ki je potekal v organizaciji Inštituta za slovenski jezik Frana Ramovša leta 2008, je pripravil sintetični pregled kritik SSKJ in ga leta 2009 objavil v članku z naslovom Kritične misli in zamisli o SSKJ.

Zasnovi enozvezkovnika je bila namenjena tudi kritična analiza publicističnih virov za slovar v članku z naslovom Publicistika in slovar (1993). Publicistična zvrst jezika je vedno bolj vplivna, zato mora gradivo za slovar vsebovati ustrezen delež tovrstnega gradiva. Müller predlaga delitev publicizmov na »novinarsko, publicistično, javnostno in neknjižno javnostno skupino«. Še isto leto pa je v zborniku Jezik tako ali drugače predstavil svoj pogled na enozvezkovni razlagalni slovar, ki pa, kot je bilo rečeno, ni bil nikoli realiziran.

Širino Müllerjevega jezikoslovnega zanimanja kažejo tudi kritični pogledi na slovenska pravopisna pravila, ki so izšla leta 1990. V prispevku Novo slovensko pravopisje, izdanem leta 1991, je pregledal vsa kritična mnenja in opozoril na nekatere manj ustrezne rešitve (npr. pisava skupaj in narazen).

Ob delu za splošni slovar se je Müller ukvarjal tudi s terminologijo v SSKJ in zunaj njega. Leta 1984, v času pred izdelavo Slovenskega medicinskega slovarja, je v prispevku Nekatere značilnosti sodobnega slovenskega anatomskega izrazja, ki je bil predstavljen na znanstvenem srečanju Slovenska medicinska beseda, ob analizi vidikov anatomskih poimenovanj (»po lastnosti, mestu, opravilu, po kaki osebi ali splošni sistematiki«) opozoril na delno jezikovno svobodo uporabnikov strokovnih izrazov. Strokovnjakom ne more nihče vsiljevati domačega izrazja, že ustvarjeno in uporabljano pa je smotrno ohranjati.

Naslednje leto (1985) je za 4. simpozij tehniške besede pregledal slovenske tehniške slovarje. Ugotovitve je objavil v članku Načela in uresničitve tehniškega slovarstva.

Leta 1995 je v časopisu Sava (poslovne skupine podjetja Sava) ocenil novi gumarski slovar kot pomembno pridobitev za jezik in stroko.

Tako je bil leta 2001 ob neperspektivnosti vztrajanja v leksikološki sekciji njegov prihod $\mathrm{v}$ sekcijo za terminološke slovarje popolnoma samoumeven. Tudi 
zato, ker je že sodeloval pri Angleško-slovenskem slovarju konfekcijske tehnologije avtorice Metke Brkan, ki je izšel leta 2001, leta 2003 pa pri slovarju hidroloških izrazov v angleščini, francoščini, nemščini in slovenščini, ki je objavljen tudi na spletu 〈ftp://ksh.fgg.uni-lj.si/acta/a32_1.pdf $\rangle$.

V sekciji za terminološke slovarje je prevzel delo za pravnozgodovinski terminološki slovar, ki je bilo že nekaj časa na slepem tiru. Jakob Müller se je najprej razgledal po slovenskem pravnem slovaropisju. Leta 2002 je v Zagrebu objavil prispevek Slovenski večjezični pravni slovarji, naslednje leto pa v Jezikoslovnih zapiskih pregled Dvojezična pravna slovarja Ivana Navratila. V tem času je dozorela zamisel, kako oblikovati pravnozgodovinski slovar. Predstavil jo je na mednarodni poletni terminološki šoli v Ljubljani, ki jo je leta 2008 priredila sekcija za terminološke slovarje, in jo objavil v zborniku Terminologija in sodobna terminografija leta 2009. Nastajajoči pravnozgodovinski slovar bo terminološki (iztočnice so termini), slovenski (iztočnice so slovenske ne glede na jezik pravnega vira, razlagalni jezik je prav tako slovenski), zgodovinski (zajema izrazje slovenske pravne zgodovine in ga umešča $v$ čas in prostor), večjezični (navajajo se nemški in latinski izvirniki slovenskih iztočnic), razlagalni (pojmi so razloženi, lahko vsebujejo tudi različna pojasnila), iztočnice slovarja so termini, zapisani po pravilih zdaj veljavnega pravopisa in opremljeni z nujnimi jezikoslovnimi podatki. Slovar bo obsegal termine od druge polovice 6 . stoletja do zemljiške odveze leta 1848 , uporabljane na slovenskem ozemlju, namenjen pa bo zlasti pravnim strokovnjakom. Gradivo za slovar obsega pravno izrazje zgodovinskih pravnih virov in izrazje pravnih in splošnih zgodovinarjev o pravu navedenega obdobja. Gradivo obsega 450 naslovov knjig in člankov in se stalno dopolnjuje. Ker večinoma ni digitalizirano, ga je treba skenirati. Za pridobivanje terminoloških kandidatov je bil izdelan program Konkord. Konkordančna zbirka obsega 12.000 konkordanc iz 3,4 milijona besed.

Delo za slovar poteka po korakih: (a) na podlagi besedilnega korpusa za slovar se sestavi seznam terminoloških kandidatov, (b) na podlagi pravnozgodovinskih meril se sestavi seznam upoštevanih pravnih področij, (c) na podlagi terminografskega koncepta se sestavi seznam terminov, (č) s katerega se izbirajo jedrni termini in njim pripadajoči termini, ki sestavljajo terminološko polje, (d) razlage oblikujeta področni in terminografski strokovnjak, (e) slovarski članek se opremi s področnimi oznakami in potrebnimi pojasnili, (f) vpišejo se z iztočnico sistemsko povezani termini in $(\mathrm{g})$ tujejezični ustrezniki.

Na taki zasnovi temelječ slovar zahteva veliko dela sodelujočih pravnih zgodovinarjev, terminografa in tehničnih sodelavcev. Kot pravni zgodovinarji sodelujejo profesorji Pravne fakultete Univerze v Ljubljani, zlasti Vladimir Simič in Katja Škrubej. Ogromno tehničnega dela (skeniranje, urejanje skeniranih besedil ipd.) je opravila tehnična sodelavka Karmen Nemec. Jakob Müller ni samo slovaropisni urednik slovarskih člankov, ampak za vsako iztočnico pripravi razlagalna izhodišča. Realizirani slovar bo zagotovo spadal v vrh tovrstnih evropskih del. Njegov največji problem je premajhno število sodelavcev, terminografov in pravnih zgodovinarjev. Slovar in njegovo kvaliteto naj ilustrira primer obdelave termina župan:

župàn -ána, leta 777 jopan in zoapan m 1. plem. od naselitve do 10./11. stol. vodja župe 
GL tudi: ispan

lat.: potestas, praetor, rector, supanus

2. ob prehodu $\mathrm{v}$ hubno gospodarstvo vodja župe, ki mu zemljiški gospod poveri določene upravne in sodne naloge: razglaša zahteve gospostva, ob proščenju daje hrano in pijačo deželskemu sodniku, gorskemu sodniku in uradnikom gospostva, kadar imajo opravek $v$ vasi, za nagrado pa uživa županico ali župnico

PRIM.: majer, rihtar

lat.: praetor

3. v fevdalizmu vodja soseske, ki tudi za zemljiškega gospoda opravlja določene upravne naloge, za nagrado pa je njegova huba manj obremenjena $z$ dajatvami

S: soseskin župan

4. avt., v fevdalizmu starešina soseske, ki je včasih tudi prisednik deželskega sodišča

5. avt., v fevdalizmu kdor načeljuje po različnih vaseh raztresenim kmetom enega gospostva

6. mest., od 16. stol. voljeni predstojnik mestnih avtonomnih organov, ki ima upravne naloge

7. od 2. pol. 18. stol. kdor po pooblastilu državnega organa za državo opravlja najpreprostejše upravne naloge

PRIM.: birič, dekan, dvanajstija, gadmar, gastald, jurat, petar, požup, preko, rihtar, sodin, višji rihtar, župa, županica, župnica

GL tudi: gorski župan, sosečki župan, soseskin župan, vaški župan, županska huba, županska pravda

Po letu 2000 se v Müllerjevih člankih intenzivneje kot prej kaže zanimanje za začetek slovenskega knjižnega jezika ter rabo in pomen poimenovanja Slovenci. Leta 2001 je v Jezikoslovnih zapiskih objavil članek Riglerjeva teza o začetkih slovenskega knjižnega jezika v številkah, ki je nastal kot odgovor na očitek enega mlajših slovenskih literarnih zgodovinarjev (ki ga J. M. ne imenuje), da Rigler pri analizi protestantskih besedil ni bil dovolj natančen. Očitke je Müller na podlagi gradivske obdelave nedvoumno zavrnil. Tematiko Raba poimenovanj Slovenci in Sloveni v 16. stoletju, ki je zdaj ob pravni zgodovini v središču njegovega raziskovalnega zanimanja, je predstavil na Škrabčevih dnevih in objavil v zborniku Države, pokrajine, narodi, ljudstva in njih kulture ter znanosti v Škrabčevih delih (2002). V zborniku prispevkov z mednarodnega simpozija o slovenskem knjižnem jeziku 16. stoletja je objavil pregled teorij o temelju/temeljih slovenskega knjižnega jezika, v Japljevem zborniku (2010) pa prispevek Kranjstvo in slovenstvo Jurija Japlja, ki ga je predstavil na simpoziju o Juriju Japlju (2009). Na intenziven študij te problematike kaže tudi njegov nastop decembra 2011 na simpoziju, ki ga je organiziral Svetovni slovenski kongres, s prispevkom o tujih in domačih lingvonimih in etnonimih v zvezi s Slovenci.

Če se ob koncu tega kratkega in nepopolnega zapisa vprašam, kdo je Jakob Müller, je moj odgovor preprost: Jakob je človek, ki se nikoli ne zadovolji s preprostimi odgovori, večni iskalec, zanimiv sogovornik in prijeten sodelavec.

Marjeta Humar Foto Marko Zaplatil 